\title{
Student housing and the slummification of the University of Zululand village in KwaDlangezwa, South Africa
}

\author{
Nothile P. Ndimande* \\ University of Zululand, South Africa
}

This paper examines the slummification of a university village in post-1994 South Africa. Universities are considered to be the main influence on the character of the host town and its spatial development. Although little work has been done in global southern rural contexts, researchers have studied the impact of students on host towns, and processes such as studentification. By examining the heterogeneous associations at play here it can be argued that relationships among actors are characterised by disconnections, and incongruent, often conflicting actions. In consequence, and ironically, these planning processes have transformed the village into a slum, a paradoxical response to the need for student housing. Drawing on qualitative methods, this paper examines the institutional actors and processes that led to the slummification of the village, drawing out the complex and conflicting roles of local and traditional authorities and the actions of the University.

Key Words: Rural university, rural space, student housing, slummification, studentification.

Article Info: Received: February 9, 2017; Revised: April 27, 2018; Accepted: May 2, 2018; Online: May 25, 2018.

\section{Introduction}

A number of studies have examined the impacts of students on their host communities or host cities (Gumprecht, 2003; 2007, Allison, 2006; Powell and Barke, 2008; Vandergrift et al., 2012). These studies examine in detail concepts such as the studentification of towns and residences (Allison, 2006), student ghettos (Hubbard, 2008) and gentrification (Smith, 2008). Others have examined the relationship between planners and universities and how universities shape the plans of towns and cities. Numerous studies on studentification

\section{* Correspondence address}

Address: Department of Geography and Environmental Studies, University of Zululand, Private Bag x1001, KwaDlangezwa, 3886, KwaZulu Natal, South Africa

Phone: +27359026330 | Email: ndimanden@unizulu.ac.za

(C)2018 Human Geographies; The authors 
have been done in the global north but only a few in the global south, examples of the latter being Donaldson et al. (2014) in South Africa, He (2014) in China, and Sabri and Ludin (2009) in Malaysia. They all draw attention to urban areas and leave a gap on the subject of rural studentification in the global south.

The University of Zululand was established in 1960 in the village of KwaDlangezwa on land that was donated by the Mkhwanazi Traditional Authority (UniZulu Strategic Plan, 2008-2011; University of Zululand, 2010). The establishment of the University of Zululand was preceded by the promulgation of the Extension of University Education Act in 1959 (Nkabinde, 1981). The Extension of University Education Act aimed to regulate university education for non-white South Africans and designate institutions for various racial and ethnic groups. Nkabinde (1981) argues that the Extension of University Education Act caused acrimony because it designated the University of Zululand for Zulu-speaking students, an ethnic stipulation which was divisive. As a result, some South Africans, especially black intellectuals did not identify with the University because it was emblematic of apartheid and inferior education.

Racial and ethnic stipulations of the Extension of University Education Act designated most black universities in the homelands. Homelands were mostly rural and geographically isolated with limited economic productivity and substandard infrastructure (Aliber, 2003). Changes in the political landscape after 1994 saw the dominance of the discourse of transformation, equality and redress in the higher education system (Barnes, 2006). In 2002, the University of Zululand became a comprehensive university tasked with expanding the range and variety of its academic offerings (University of Zululand Strategic Plan, 2008-2011). The University calendars from 2000 to 2014 indicate significant growth in the student numbers, from 6,000 in 2000 to 16,000 in 2014. This growth poses challenges for student accommodation and dilemmas for spatial planning and development for the government institutions.

Examination of specific heterogeneous associations is necessary for mapping institutional arrangements of rural governance, particularly disconnections and incongruences between institutionalised and non-institutionalised actors in KwaDlangezwa and for tracing the trajectory of how studentification produced the slummification of a university village.

This paper defines slummification as the development of new informal settlement as a response to the housing shortage and the gradual transformation of an existing village into an informal settlement. It can, therefore, be argued that slummification contradicts South Africa's higher education discourse of transformation and equality.

The paper draws attention to key players in local communities, particularly landowners, who, in rural governance disconnections, have built informal housing for students, transforming themselves into landlords. On the one hand, this is a study of 'studentification gone wrong', on the other hand, it is an analysis of the 'creative destruction' of rural space, the transformation of a village formerly sustained by subsistence sugar cane farming and forestry to an economy built around a slum. The University creates the demand for housing, paradoxically creating a slum, an opportunity for local livelihoods and a new planning challenge for local governance, marked by a power shift from formal institutional actors to informal and non-institutionalised actors. 


\section{Beyond 'town and gown' debates: the complexities of local governance in southern contexts}

The provision and development of student housing is a challenge for many universities around the world as a result of the ongoing expansion of higher education institutions and student numbers (Bromley, 2006; Thomsen and Eikemo, 2010). The shortage of student housing offers an opportunity to residents and private developers to provide accommodation to students as a way of generating income. The provision of such accommodation intensifies the relationship between the university and the host-town. Some students are left with no choice but to seek housing in the neighbourhoods outside the university, resulting in the studentification of host towns. Students have the ability to enhance the character of the host town. Therefore studentification helps planners theorise the role of students in urban planning (Pickern, 2012).

Various studies have examined the impact of studentification on host towns and cities (Allison, 2006; Powell and Burke, 2008; Vandegriftet al., 2012; Perkin, 2012; Donaldson et al., 2014). Impacts can be either positive or negative. Positive impacts are, among others, increased spending power which boosts local businesses, increased property market (gentrification). Some host towns have recognised the importance of university students and have actively integrated the student culture into the host-town brand (Insch and Sun, 2014). Host towns are known to derive economic benefits from their student populations, hence they brand themselves as student-friendly towns or cities in order to influence the choice of potential students both nationally and internationally. This means that the image of a city is of extreme importance not only for students but also for the university employees, the residents and the municipalities. Students are likely to choose prosperous towns with a variety of amenities over towns and cities that are characterised by social problems such as crime and poverty (Bromley, 2006).

Studentification may also create resentment and conflict between the university and the town officials. Students are accused of the ghettoisation of host towns, increased criminal activities, and overcrowding (Bromley, 2006; Smith, 2008). Such developments are due to the fact that students are temporary communities with no identity or association with the host town.

Ghettoisation is characterised by dilapidated houses or blocks of flats, driving some residents to relocate. Another source of conflict, indicated by Donaldson et al. (2014), is nonsensical behaviour associated with alcohol consumption, partying and noise in the neighbourhood. In some instances students are also accused of inflating rental fees, residents arguing that they disadvantage the low-income residents.

While this literature is rich and useful in northern university town contexts, in global southern settings like rural KwaZulu Natal, studentification of a rural village is far more complex. It brings together a range of actors with varying power and authority, as well as legitimacy, a context rife with conflict and resistance.

Hubbard (2008) calls on researchers to move their focus from student occupation and redirect it to the emergence of spaces from 'specific networks of heterogeneous association'. Specific networks of heterogeneous association 
enable us to examine connections and disconnections which may exist among various actors in the production of space. In the analysis of relationships between universities and their surrounding communities in the UK, Hubbard (2008) argues that they could either be mutual or disconnected. Reciprocal relations exist where the university plays a central role in the local economy either through job creation or sustenance of local businesses. The failure to recognise such contributions results in disconnection.

\section{Local governance and the creative destruction of rural space}

Rural areas undergo some form of transformation as they respond to forces of change, be they socio-economic, cultural, or environmental and land use (Chigbu, 2013; Mitchell, 2013). A number of factors such as government policy, economic performance and population may induce rural transformation. Such changes often manifest themselves spatially and may change the form and function of a rural area.

Geographers have primarily used a three-fold model of rural space (trial by space) and creative destruction to explain the transformation of rural spaces, particularly in the global north (Mitchell and Vanderwerf, 2010). Trial by space, a concept borrowed from Henri Lefebvre, is used by Halfacree $(2006,2007)$ to explain the transformation of rural spaces and the struggle for rural identity.

Halfacree explains space production by using three facets of the rural space, namely, the rural locality, formal representation, and everyday lives. The 'locality' describes the rural locality as the location of production and consumption. 'Formal representation' refers to the articulation of rural space in policies, local and development plans and businesses plans. 'Everyday lives' of the rural people looks at how people produce and shape rural spaces in their daily activities. The relationship among the three facets determines spatial coherence, which is both temporal and dynamic. This relationship may take any of three forms, namely, harmonious, contradictory or chaotic. Harmony and coherence are a function of consistent values and ideas held, while deviations from values may result in contradiction and chaos (Halfacree, 2007; Mitchell and Vanderwerf, 2010).

In his critique of Halfacree's model, Frisvoll (2012) added 'power' as a valuable facet in understanding the transformation of rural spaces. Frisvoll argues that Halfacree's conceptualisation of rural space has limitations since it is not explicit about the actors and ignores the significance of power in the production of rural space. Frisvoll suggests an extension to Halfacree's conceptualisation of space by incorporating three hubs, namely, immaterial, material and personal. The immaterial hub is an extension of Halfacree's social representation; it looks at both the formal and informal rules guiding actors and their actions. The material hub refers to actors' possessions and the relations between those who have and those who do not have. The personal hub focuses on the individual actors, their careers, livelihoods, and their aspirations for better living. These hubs emphasise the importance of actors and the power entanglements that exist. Frisvoll's addition enriches the theoretical framework of space production. 
The notion of 'creative destruction', used by Mitchelle (1998), was adopted from Joseph Schumpeter who used it to explain the displacement of one economic activity by another. This concept has been used in geography to explain transformation that has been stimulated by the commodification of heritage in Canada (Mitchell et al., 2001; Mitchell and de Waal, 2009; Mitchell and Vanderwerf, 2010; Mitchell, 2013). As new landscapes are developed to cater for the growing interest of the consumers, the pre-development landscapes are destroyed. Rural idyll is the key attribute of the rural space in this model (Mitchelle et al., 2001).

Creative destruction brings the concept of power to the centre of the analysis of governance and space transformation. It helps to trace the dynamics of governance and also the opportunities and constraints that are part and parcel of the transformation of rural areas. It disrupts the rural idyll and power politics stereotypes held by many and helps to show how power is shaped and produced. These are the central questions for this paper: how does rural governance work in practice and how is governance connected to the production of the slum? In these processes, who has power and authority in practice, and what are the longer-term consequences for rural space and university-community relations?

\section{Research methods}

This is a qualitative study which employed a case study approach to understanding the slummification of KwaDlangezwa village, the home of the University of Zululand (Figure 1). The University of Zululand is located in north-eastern KwaZulu-Natal. Figure 1 shows the location of the University within the City of uMhlathuze. The strength of the case study research method is the use of more than one data source to improve data credibility (Baxter and Jack, 2008). These methods include the use of interviews, observations, and the collection of relevant documents. The village was chosen as a research site because it is experiencing rapid growth of informal housing as a response to the growing demand for student accommodation. The research has observed slummification of the village for almost a decade.

Data were collected between April 2014 and February 2015. Purposive sampling was used to select respondents. This technique is useful in identifying and selecting participants who, according to Patton (1990) are 'information-rich cases' and are worthy of in-depth study. Information-rich cases are people who have knowledge about the phenomenon under investigation. It is also useful when researchers construct historical realities or describe unfamiliar phenomena (Kumar, 2011). The study yielded 22 in-depth interviews, comprising 12 landlords, 3 municipal officials (1 environmental planner, 1 land use specialist, and 1 housing official), 2 local leaders (a ward councilor and the local herdsman representing the local traditional authority), 3 University officials (2 physical planning officials and 1 manager from the Student Services Department), a member of the student governance council, and the Ingonyama Trust Planner. A considerable amount of time was spent negotiating appointments and getting consent from the landlords and building rapport. Initially, some landlords were 


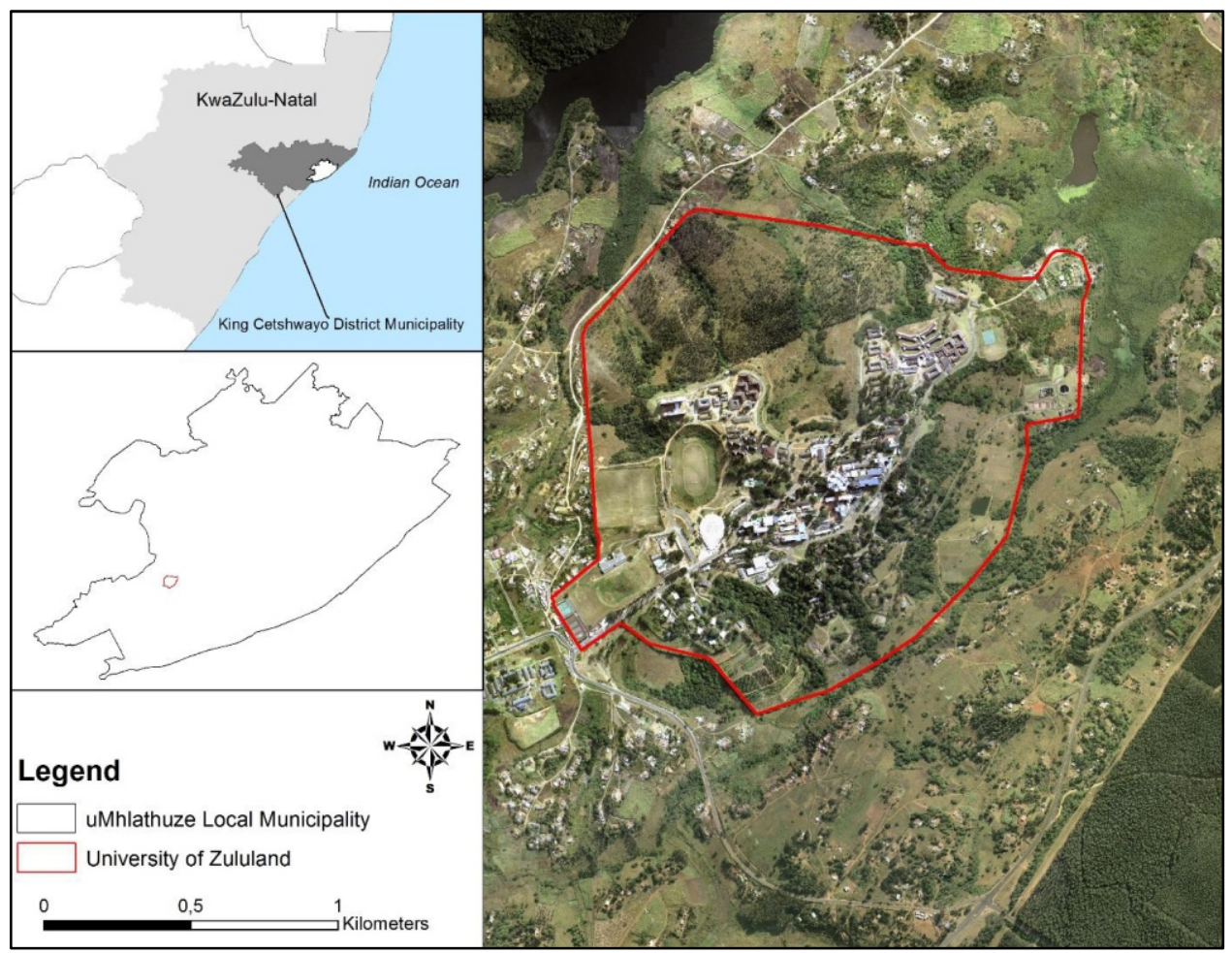

Figure 1. The location of the University of Zululand

sceptical because they suspected that the study wanted to expose living conditions in their properties. After lengthy explanations and negotiations, consent was granted, and the researcher was allowed to conduct interviews. In-depth interviews are useful because they assist researchers to understand views on processes, norms, decision making, belief systems, mental models, interpretations, hopes, expectations, and fears (Guest et al., 2013). Interviews with the identified informants enabled the understanding of history and processes that led to the development of a slum around the University.

The first step of analysis was the transcription of each interview. Transcribing after each interview is helpful since the interviewer has a better recollection of the details given during the interview (Magnusson and Marecek, 2015). This resulted in 22 interview transcripts. Each interview transcript was read and coded manually. Common words and phrases that appeared in the interview scripts were used as codes; for instance, words and phrases such as 'chaos', 'frustration', and 'no trust', emerged when we talked about the nature of relationships. A master list grid with all the codes was created in MSWord, and common codes were identified, colour coded, organised and regrouped into themes such as 'roles and responsibilities', and 'power and authority'. Later, themes were classified according to the Halfacree's trial by space framework to answer research questions.

There are documents which were useful for this study. Bowen (2009) argues that use of documents adds value in qualitative research in a number of ways; for instance, they provide historical background, insights and supplementary information, they assist researchers to ask appropriate questions and verify 
information obtained from other sources, and they are useful tools for tracking changes and developments. Inter alia, this study used University calendars from the year 2000 to 2014, University magazines (such as UNIZULU '99 and UNIZULU 1960-2005), and the University's strategic plan 2008-2011, University of Zululand Self-Evaluation Portfolio 2010, and Institutional Operational Plan 2006-2009 to trace student enrolments, infrastructure development, and development of campus residences. Other useful documents were the City of uMhlathuze's Integrated Development Plan (IDP) 2012/2017, the Revision of Spatial Development Framework 2007, and the Provision of Services to Unplanned, Informal and Illegal Properties throughout uMhlathuze's area of Jurisdiction, and the KwaDlangezwa Draft Precinct Plan 2014. The Provision of Services to Unplanned, Informal and Illegal Properties throughout uMhlathuze's area of Jurisdiction is the municipal response to slummification in the city, including the KwaDlangezwa slum. Documents were examined, and later themes were identified and aligned with interview themes.

\section{The University of Zululand's slum: Key actors in KwaDlangezwa}

It was essential to identify governance actors in KwaDlangezwa, determine their roles and responsibilities, and understand how they are connected to the growth of the slum in KwaDlangezwa. This section discusses the roles and interests of the following actors:

The University of Zululand: This is an academic and research enterprise attracting students and staff who stimulate and sustain the local economy. The University of Zululand has seen a significant increase in student numbers since 2000 (CHE UniZulu Profile, 2010). In fact, the numbers have doubled beyond the University's accommodation capacity. One could attribute this growth to firstly, improved national matriculation (Grade 12) pass rates enabling entry to university, and secondly, government assistance through the National Student Financial Aid Scheme (NSFAS), a government-funded scheme which offers financial assistance to students from poor families. For instance, in 2007, 39\% of full- time students were NSFAS beneficiaries. Thirdly, the University of Zululand is one of the cheaper universities in the country, according to the Council on Higher Education Advice and Monitoring Directorate (2010), thus making it an affordable option for more students.

There is a massive gap between the growth of student numbers and accommodation available for them. The University accommodates only $30 \%$ of the registered students (Department of Higher Education 2011). According to the Student Services manager, in 2014 the University bed capacity was 3815 on the KwaDlangezwa campus, with a further 1,000 leased from formal accommodation facilities in the neighbouring residential areas (Richards Bay, Felixton and Mthunzini-Obanjeni). The University is in the process of building new campus accommodation facilities on campus.

City of uMhlathuze: KwaDlangezwa is under the City of uMhlathuze (also known as uMhathuze Local Municipality), which falls under King Cetshwayo District Municipality. The City of uMhlathuze delivers essential services to the University, the formal township, and KwaDlangezwa village. 
The local landlords: These are locals who own land around the University and have built structures close to the University to provide affordable accommodation to students. They also sell land to other potential landlords. For landlords, student accommodation has become their main source of income. They view students as potential tenants and, more often than not, they have a good relationship with them. Competition for land and students is intense among the landlords.

For the locals, rural space is their home, a space they identify with. It provides an opportunity to enhance their livelihood. Growth in student numbers and the University's inability to accommodate students create three types of economic opportunities for the residents of KwaDlangezwa. Firstly, there is an opportunity to sell land to potential developers who build student accommodation. Secondly, they provide accommodation to students who cannot find or cannot afford campus accommodation, and thirdly, it is an opportunity for both formal and informal entrepreneurs to provide products and support services to the University community.

Traditional authorities: The Mkhwanazi Traditional Authority is the custodian of land in KwaDlangezwa village. It is represented on the University Council, the governing and accounting body of the institution. Traditional authorities are responsible for land allocation and resolving land-related disputes.

Ingonyama Trust Board (ITB): This is an accounting authority for the administration of communal land in KwaZulu Natal. It was established regarding the KwaZulu Natal Ingoyama Trust Act 3 of 1994 and was later amended by the KwaZulu-Natal Ingonyama Trust Amendment Act 9 of 1997. Its chief responsibility is to ensure sustainable use of land in order to improve the quality of lives of the rural communities and comply with laws that govern land use management in South Africa (ITB 2011-12, 2012-13).

When examining the relationship between the identified actors in the production of the rural slum, it can be argued that landlords are the paramount actors in KwaDlangezwa because they provide student accommodation in the village. Figure 2 illustrates the types of relationships amongst the governance actors in KwaDlangezwa. There is no formal relationship that exists between the University of Zululand and the landlords. On the one hand the landlords maintain that they have always provided student accommodation and that, in the past, the University has never shown interest and has isolated itself from its immediate surroundings. They further argue that the University missed an opportunity to engage with the traditional authority or the landlords to discuss off-campus accommodation, it detached itself from the landlords and seemed oblivious to slum development. During the interviews, one of the landlords indicated they have no relationship with the university:

I have no relationship with the university. I assist students because they are desperate. They (students) come to us. The University does not have enough accommodation. I have a relationship with students, my tenants. The university does not give me any assistance. They don't help us. They don't help students.

Consequently, landlords have defied the University's recent proposal for a formal relationship. On the other hand, in 2013, the manager at the Students 


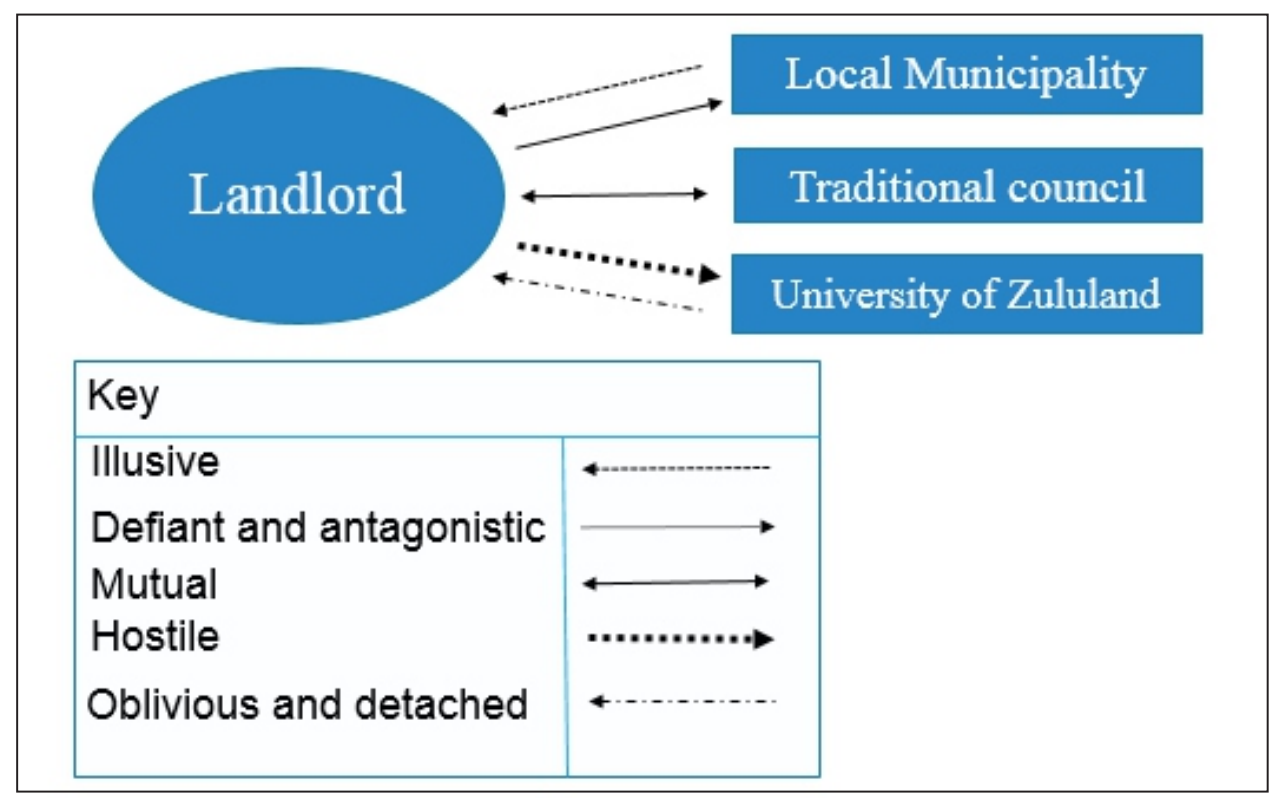

Figure 2. Relationship between landlords and the local municipality, Traditional Council and the University of Zululand. Note: Author's own illustration

Services Department (SSD) invited landlords to negotiate the implementation of standards of student accommodation set by the Department of Higher Education, but the landlords turned down the invitation and resisted any move made by the University officials. As the SSD manager reported:

We invited landlords to a meeting where we wanted to assist them on how to meet accommodation standards set by the Department of Higher Education. Unfortunately, our invitation was received with hostility, and no one attended the meeting, so we basically don't know how to engage with them.

Even though Mkhwanazi Traditional Authority is part of the University Council, the governing authority of the University, there are no collaborative efforts initiated to address slummification of the village. University has conveniently thrust aside the slum at its doorstep.

The relationship between the municipality and the landlords is illusive, as the councillor and municipal planners are unable to confront slummification because their political permanence depends on the local constituency. As a result, leadership is noncommittal. However, there is mutual understanding between the traditional leadership and the landlords.

The relationship between the municipality and the University is one of clientage, as uMhlathuze supplies all the necessary services to the University and regulates various forms of development within the University's premises. It also supplies services to the local villagers but is unable to regulate and guide development in the village. Its attempt to act in KwaDlangezwa encounters hostility and defiance. 


\section{Rural spaces and the shifting powers of local actors}

Like most spaces, KwaDlangezwa is contested by actors who have diverse and competing values, ideas, and interests. Such contestations shape and influence rural space production. Woods (2012) argues that space contestations result from tensions between the material demands on rural space from various types of development and the discursive representation of rurality that shape the everyday experiences and the perceptions of those who live in the rural areas. The study used Halfacree's 2006, 2007 three-fold model of space and Frisvoll's 2012 power argument to interrogate space production and power shifts in KwaDlangezwa.

\section{KwaDlangezwa: the locality of blurred demarcation}

In South Africa, rural areas have been incorporated in municipal wards as part of the wall-to-wall arrangement created through the Municipal Demarcation Act 27 of 1998. Ideally, this should mean that municipalities and traditional authorities have well-defined roles and responsibilities in their administrative and management duties. However, this is not the case. Even though the rural villages are part of the municipalities, they remain sensitive territories which both the provincial and the municipal structures find hard to deal with. The KwaZulu Natal Planning Commission (KZNPC, 2010) acknowledges tensions, disjunctures, gaps, silences, and vagueness in policy and the absence of a functional relationship among various actors in rural areas.

In principle, wall-to-wall demarcation should enable municipalities to service rural areas and to guide and regulate various forms of development there. On the one hand, the municipal officials have expressed their concerns over the absence of legislation which would empower them to guide spatial planning in KwaDlangezwa, because it is under traditional leadership. As far as they know, Ingonyama Trust has the responsibility of spatial planning in all areas under traditional authorities. On the other hand, in an interview, the Ingonyama Trust planner insisted that wall-to-wall demarcation empowers municipalities to plan and manage land use in rural areas, meaning that the Municipality concerned should act on matters of planning and land use management.

During the interviews, uMhlathuze municipal planners expressed frustration with regards to their inability to influence planning in the rural areas because of territorial politics. Conflicts exist as there are divergent opinions on who has power over land and how land should be used or allocated.

\section{Formal representation of KwaDlangezwa}

Two divergent views emerged during the interviews with municipal planners when KwaDlangezwa the locality was discussed. The first view is optimistic about the area. Such optimism is expressed in the KwaDlangezwa Draft Precinct Plan (City of uMhlathuze, 2014) which is a collaboration between the municipality and the Department of Rural Development and Land Reform. The plan, according to the municipality, aims to address the spatial, economic, and infrastructural discrepancies which exist and will provide a platform to harness 
local growth and development potential. The plan is to revitalise the image of the area and stimulate economic development through the establishment of commercial centres. These commercial centres will serve the University and the surrounding communities.

The second view, which has pejorative overtones, sees KwaDlangezwa as a development predicament because of the uncontrolled slummification of the village. Slum development has no proper layout plan and encroaches on land reserved for other land uses. It is a space of illegal activities as some slums are illegally connected to municipal services. Holders of this view also see KwaDlangezwa as a space of resistance as the locals continue to invade and encroach on land not designated for other uses and rebel against any form of regulation and formalisation. The municipality perceives the rural areas as the culmination of loopholes in the political system and government policies. This view stems from the fact that municipal officials have limited powers to intervene in the communal lands under the traditional authorities.

The municipality has prepared at least two documents that have implications for the informal settlements around the University:

(i) The Provision of Services to Unplanned, Informal and Illegal Properties throughout the uMhlathuze's area of Jurisdiction (uMhlathuze Local Municipality, 2010). This document is an appeal to the Mkhwanazi Traditional Authority and Ingonyama Trust to resolve the issue of disputed land and a proposal for better land use management for the Mkhwanazi Traditional Authority. It was presented to both municipal council and the traditional council in 2010 but has never been approved or accepted by the two institutions.

(ii) The IDP 2012/2017 - Chapter on Municipal Housing Plan, (City of uMhlathuze, 2012). This document outlines the intention of the slum clearance programme of the Department of Human Settlement. This programme is designed to look for alternative land to build low-cost housing for the poor. However, the situation in KwaDlangezwa is different because the informal settlement around the University is for transient residents. So the clearance programme is not an appropriate solution for the area.

In 2009, the Municipality researched the development of informal settlement within its geographical boundaries (uMhlathuze Local Municipality, 2010). Their research indicated that around the University of Zululand there had been an occupation of land that was proclaimed as part of the township. A boundary dispute confronts both the Mkhwanazi Traditional Authority and the Municipality. The occupants of the land claim that the land was allocated to them by the members of the traditional authority. Disputed boundaries and the lack of cooperation between the Municipality and the traditional authority on land allocation complicate service provision. The Municipality identified a need for a structured framework within which both authorities could cooperate. In its recommendations, the Municipality looked at the possibility of redrawing the boundaries so as resolve the dispute.

The KwaZulu Natal Planning Commission (KZNPC) undertook research to investigate, and provide guidelines, to address the concerns on the inability of the spatial planning tools available to cater for the rural communities (KZNPC, 2010). Among the key focus areas of the research were: looking at the responsiveness of the KwaZulu Natal Land Use Management Systems (LUMS) in 
dealing with land under the traditional authorities; establishing the extent to which the existing systems, procedures, and technical support available to the traditional councils is useful for spatial planning and land allocation purposes; and how to creatively and innovatively formulate a model that can integrate the traditional systems, LUMS, and legislative and legal requirements.

The KwaZulu Natal Planning and Development Act (KZNDPA), 6, 2008 (KwaZulu Natal Province, 2008) is silent on the issue of traditional leadership roles in planning. This often leads to tensions between municipal officials and the traditional authorities. The planning commission argues that planners should take into consideration the needs of the rural people such as agricultural land. In the case of the settlement around the University of Zululand, the municipality planners pointed out that they have already prepared a layout for the disputed area. They only require a legislative framework that will enable them to collaborate with the communities in trying to resolve the current situation and then plan future development.

\section{Everyday lives and power shifts}

It can be argued that disconnections between the University and the surrounding landlords hinder it from negotiating future developments of off-campus accommodation and also its own ability to negotiate land for its future expansion beyond the land already allocated.

UMhlathuze Municipality has noted with concern the growth of informal settlement, and they realise that if there is no control the situation could easily degenerate into chaos, and that will hinder service provision. The provision of water and electricity is a challenge as more and more people consume such services illegally, thereby crippling the Municipality's ability to plan for future provisions.

To control and regulate the development of informal settlements in the rural areas, the Municipality has resorted to land formalisation. The Municipality acknowledges that the tenure system as it exists in rural areas where land is communally owned is uncoordinated, informal and insecure (uMhlathuze Local Municipality, 2010). This is because there are no title deeds or proper layout plans that inform and shape development. During the interviews, the Municipal officials contended that formalisation of land would help to control and regulate land use, but some rural dwellers argue that formalisation of land use undermines the history, the culture and the identity of rural South Africa. A municipal planner indicated the dilemma they experience in KwaDlangezwa:

As the municipality, we are troubled by the development of the slum around the University, and it has encroached on land reserved for township growth. If we provide services (water and electricity) in such an area, it would mean that we endorse illegal occupation of land, but that if we take no action, illegal occupation of land will continue.

According to the Municipality officials, a number of the informal settlements have water and electricity, but the Municipality does not have records of informal settlements that they service. This basically means that these informal settlements are illegally connected to municipal services such as water and 
sewage as well as to the power grid. UMhlathuze Municipality would like to rectify the situation, but because of the ambiguities in the policies over spatial authority, they are unable to do so. They are concerned that their silence may be interpreted as an endorsement of illegal activities.

It can be argued that landlords dread any form of formal relationship either with the University or the Municipality. They believe that they have established a source of income for themselves without assistance. They resent both institutions for their inability to assist or intervene ten years ago:

When we started providing student accommodation, the university turned a blind eye; they were not interested in helping us. Now they want to tell us what to do. We don't want the Municipality to interfere with our business; they will impose taxes and rates on us. We will run out of business. This is a village; we don't pay rates.

There is a visible absence of connections among the actors in the network that produces rural space. The University of Zululand has not enhanced rural planning and development. It has for many years detached itself from the slum and the landlords. It is also not ready to deal with the complex rural arrangements of governance comprising both the formal and informal actors. It has missed an opportunity to shape and influence growth around its own environment, and as an academic enterprise has failed to lead and shed light on rural spatial planning and development.

The three facets of space production discussed in this section exhibit contradictory views, silences, tension and resistance among actors in KwaDlangezwa and have inhibited opportunities for coherence and symbiotic relationships. This indicates fragmentations in institutional arrangements of governance which create incongruence in the rural governance of this village.

\section{Creative destruction of KwaDlangezwa: The transformation of a village}

The underlying premise of creative destruction is that in the absence of proactive planning, business activities in the commodification of space will lead to the destruction of the rural idyll or the rural character that most people appreciate (Mitchell and De Waal, 2009). The absence of pro-active planning by either the University or the Municipality has created an opportunity for informal economic activity to thrive in the local economy. It has also created space for contradictory identities. While in its strategic vision and missions the University of Zululand describes itself as a leading comprehensive university and emphasises the quality of output, its surroundings exhibit disorderliness.

Before the commodification of rural space in KwaDlangezwa homesteads were surrounded by small sugar cane fields, eucalyptus forest plantations, and fruit trees. Forest plantations and sugar cane were used as either the main source or a supplementary source of livelihood for generations. Agriculture was part of the village character and identity. The village has transitioned from family-based small-scale agriculture to being a provider of student accommodation. Demand for housing has created pressure for homestead owners to sell land and leased accommodation. This has transformed its traditional character 


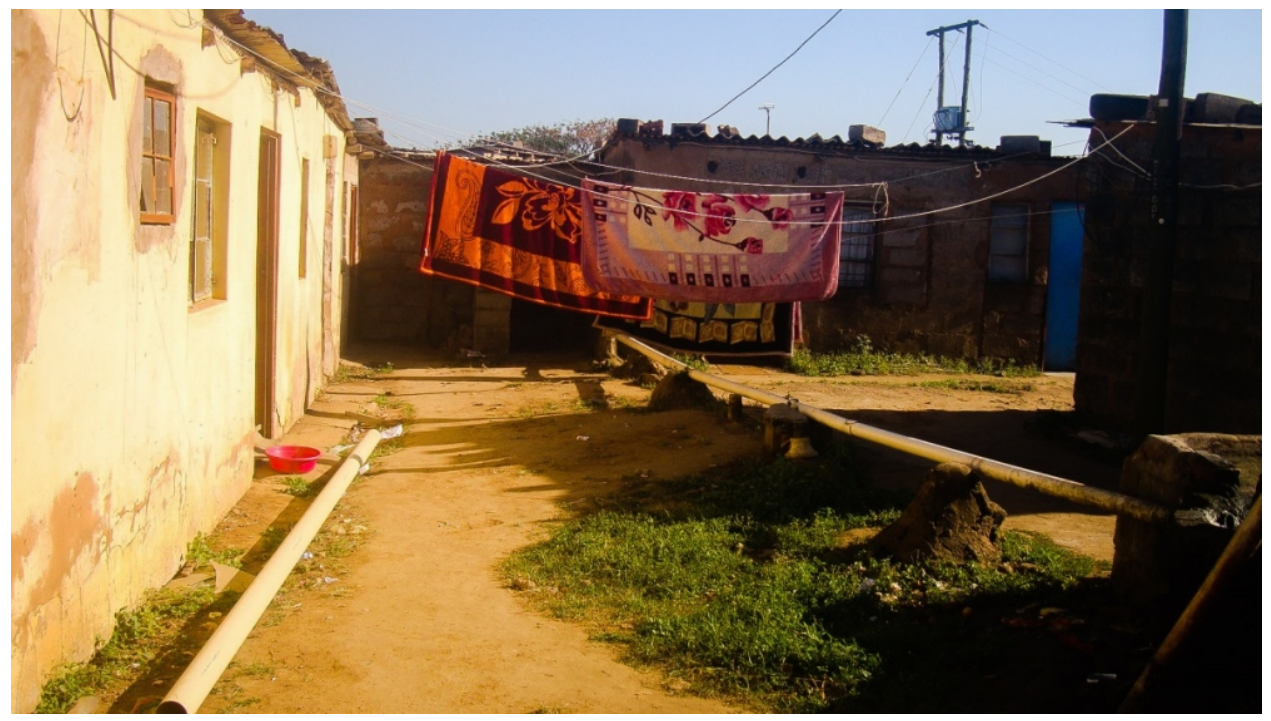

Figure 3. Typical student accommodation in the village

from one of visible vacant land to an overcrowded rural village driven by profitmaking.

The study has identified two key beneficiaries in the process of providing student housing. First are the homestead owners and local herdsmen. They own bigger pieces of land which they subdivide and sell or lease to others. Some of them have already built student accommodation. Others are desperate to sell land to get quick cash. Scrabble for land is rife. Land values are increasing, and are largely determined by their size and their proximity to the University. The transactions between the buyers and sellers have become an important part of the informal local economy.

Second are the landlords. For them the provision of student accommodation is an opportunity for income generation. Landlords indicated that there is no competition from big or well-established developers. They revealed that their income earned from student accommodation ranges from 300-3,000\$ per month. Their income is determined by the number of buildings they own and the level of occupancy. Most of the landlords interviewed claimed to have more than $80 \%$ occupancy throughout the year.

Figure 3 shows the type of accommodation local landlords provide for students. Student accommodation provided by the locals has slum characteristics. It is sub-standard, poorly constructed, and sometimes with no ventilation or furniture. Room sizes range between $9-12 \mathrm{~m}^{2}$, with each room occupied by three or four students, some places do not have proper sanitation or bathing facilities.

\section{Conclusion}

In rural South Africa, issues of studentification go beyond the 'town and gown' debates. They reflect the complexity created by multiple layers of governance of rural areas and the hostile attitudes held by locals towards formal institutions of government. A careful probe into relationships of various actors has enabled one 
to understand the production of a slum in KwaDlangezwa. Slummification of a rural village is a result of chaotic and incongruent relationships among networks of heterogeneous actors associated with studentification in rural South Africa. Dilemmas, silences, ambiguous policies and inaction by the formal institutions of governance have empowered landlords to steer slummification of the village in a way that best suits their needs and has encouraged them to be territorial and resist any form of regulation or plans to formalise relationships either with the University or the Municipality. There's a discord between the municipal plans and the actual drivers of slummification such as the absence of relationships amongst actors.

This study has contributed to existing studies in two ways. First, this study has advanced knowledge and understanding of the relationship between universities and host communities by interrogating the dynamics of studentification within the context of a rural village in a post-apartheid South Africa and providing insight into how studentification of a village has produced a slum. In this case, the village has experienced the rapid growth of informal settlements, a response to the need for student housing in South Africa. Second, the study has not only scrutinised relationships among various governance actors but has also shown how the power has shifted from institutionalised actors (University, Municipality and Ingonyama Trust) to the landlords.

The main limitation of this study is that students who are tenants in the village were not included in the study. There is a need to augment this study to include students because they are key actors in the village. Hubbard (2008) further argues that the invisibility of students in local politics and planning compounds the disconnected relationship.

In order to address the gaps in governance and ensure the effectiveness of governance institutions, there is a need to re-examine the roles and responsibilities of local municipalities in South African villages and empower municipalities to assist traditional authorities with rural planning to curb the growth of slums in the villages. With specific regard to this study, there is also a need for the University of Zululand to pay attention to its surroundings and assist in shaping future growth and development in KwaDlangezwa.

\section{Acknowledgements}

I would like to thank the Society of South African Geographers for all their support, especially Sophie Oldfield for her support and comments she gave me during the write-up. I am also grateful for the support I received from the University of Zululand.

\section{References}

Aliber, M. (2003), "Chronic Poverty in South Africa. Incidence, causes and policies", World Development, vol. 31, no. 3, p. 473-490.

Allison, J. (2006), "Overeducated, over-exuberant and over-here? The impact of students on cities", Planning, Practice and Reseach, vol. 21, no. 1, p. 79-94. 
Barnes, T. (2006), "Changing discourses and meanings of redress in South African higher education, 1994-2001", Journal of Asian and African Studies, vol. 41, no. 11/2, p. 149-170.

Baxter, P. and Jack, S. (2008), "Qualitative Case Study Methodology: Study Design and Implementation for Novice Researchers", The Qualitative Report, vol. 13, no. 4, p. 544-559.

Bowen, G.A. (2009), "Document Analysis as a Qualitative Research Method", Qualitative Research Journal, vol. 9, no. 2, p. 27-40.

Bromley, R. (2006), "On and Off Campus: Colleges and Universities as Local stakeholders. Planning", Practice and Research, vol. 21, no. 1, p.1-24.

Chigbu, U.E. (2013), "Rurality as a choice: Towards ruralising rural areas in subSaharan African countries", Development Southern Africa, vol. 30, no. 6, p. 812825 .

City of uMhlathuze, (2012), Intergrated Development Plan, 13 January 2015, (https://goo.gl/qmhppx).

City of uMhlathuze, (2014), KwaDlangezwa Draft Precinct Plan.

Council on Higher Education Advice and Monitoring Directorate, (2010), University of Zululand CHE Profile.

Department of Higher Education and Training, (2011), Report on Ministerial Committee for the Review of the Provision of Student Housing at South African Universities.

Donaldson, R., Benn, J., Campbell, M. and de Jager A. (2014), "Reshaping urban spaces through studentification in two South African urban centres", Urbani Izziv, no. 25, p. 176-188.

Frisvoll, F. (2012), "Power in the production of spaces transformed by rural tourism", Journal of Rural Studies, vol. 28, no. 4, p. 447-457.

Guest, G., Namey, E. and Mitchell, M. (2013), Collecting Qualitative Data: A Field Manual for Applied Research, Los Angeles: Sage.

Gumprecht, B. (2003), "The American College Town", The Geograhical Review, vol. 93, no. 1, p. 51-80.

Gumprecht, B. (2007), "The campus as a public space in the American college town", Journal of Historical Geography, vol. 33, p. 72-203.

Halfacree, K. (2006), "Rural space: constructing a three-fold architecture" in P. Cloke, T. Mardesen, P. Mooney (eds), Handbook of Rural Studies, London: Sage, p. $44-62$.

Halfacree, K. (2007), "Trial by space for the 'radical rural': Introducing alternative localities, representations and lives", Journal of Rural Studies, vol. 23, p. $125-141$.

He, S. (2015), "Consuming urban living in 'villages in the city': Studentification in Guangzhou, China", Urban Studies, vol. 52, no. 15, p. 2849-2873.

Hubbard, P. (2008), "Regulating the social impacts of studentification: a Loughborough case study", Environment and Planning A, vol. 40, no. 2, p. 323341.

Ingonyama Trust Board (ITB), (2011-2012), Annual Report, 17 August 2014, (https://goo.gl/7d7DTk).

Ingonyama Trust Board (ITB), (2012-2013), Annual Report, 17 August 2014, (https://goo.gl/CzqpLw).

Insch, A. and Sun, B. (2013), "University Students' needs and satisfaction with 
their host city", Journal of Place Management and Development, vol. 6, no. 3, p. 178-191.

Kumar, R. (2011), Research Methodology: A Step-by-Step Guide for Beginners, 3rd edition, New Delhi: Sage.

KwaZulu Natal Planning and Development Commission, (2010), Land Use Management Systems in rural areas.

KwaZulu Natal Province, (2008), KwaZulu Natal Planning and Development Act No 6, 2008.

Magnusson, E. and Marecek, J. (2015), Doing interview-based qualitative research: A learner's guide, Cambridge: Cambridge University Press.

Mitchell, C.J.A. (1998), "Entrepreneurialism, commodification and creative destruction: a model of post-modern community development", Journal of Rural Studies, vol. 14, no. 3 p. 273-286.

Mitchell, C.J.A. (2013), "Creative destruction or creative enhancement? Understanding the transforming rural spaces", Journal of Rural Studies, vol. 32, p. 375-389.

Mitchell, C.J.A. and De Waal, S.B. (2009), "Revisiting the model of creative destruction: St Jacobs, Ontario a decade later", Journal of Rural Studies, vol. 25, no. 1, p. 156-167.

Mitchell, C.J.A. and Vanderwerf, J. (2010), "Creative destruction and trial by space in a historical Canadian Village", The Geographical Review, vol. 100, no. 3, p. 356-374.

Mitchell, C.J.A., Atkinson, R.G. and Clark, A. (2001), "The creative destruction of Niagara-on-the-Lake", The Canadian Geographer, vol. 45, no. 92, p. 285-299.

Nkabinde, A.C. (1981), "Welcome Address: Definition of Goals" in A.J. Thembela (ed), A University on an African Soil-Towards a definition of Goals, Proceedings of a symposium held on 7-9 September 1981 at the University of Zululand, KwaDlangezwa, p.1-8.

Patton, M. (1990), Qualitative evaluation and research methods, Beverly Hills, CA: Sage, p. 169-186.

Pickern, G. (2012), "Where Can I Build My Student Housing?" The Politics of Studentification in Athens-Clarke County, Georgi", Southeastern Geographer, vol. 52, no. 2, p. 113-130.

Powell, K. and Barke, M. (2008), "The impact of students on local house prices: Newcastle upon Tyne, 2000-2005", Northern Economic Review, no. 38, p. 39-60.

Republic of South Africa, (1998), Municipal Demarcation Act 27 of 1998.

Sabri, S. and Ludin, A.N.M. (2009), "Studentification: Is it a key factor with the residential decision-making process in Kuala Lumpur?", Paper presented at the South East Asian Technological Universities Consortium (SEATUC), Johor Bahru: 3rd SEATUC Symposium Proceedings.

Smith, D. (2008), "The politics of studentification and (un)balanced urban populations: Lessons for gentrification and sustainable communities", Urban Studies, vol. 45, no. 12, p. 2541-2564.

Thomsen, J. and Eikemo, T.A. (2010), "Aspects of student housing satisfaction: a quantitative Study", Journal of Housing and the Built Environment, vol. 25, no. 3, p. 273-293.

UMhlathuze Local Municipality, (2010), Provision of Services to Unplanned, Informal and Illegal Properties throughout Council's Area of Jurisdiction, A report to 
the Community Facilitation and Housing Portfolio.

University of Zululand, (2008-2011), Strategy Plan, 20 November 2016, (https://goo.gl/KkHN7N).

University of Zululand, (1999), UNIZULU 9940 Years: Constructing the Future, KwaDlangezwa

University of Zululand, (2009), The Institutional Operational Plan 2006-2009.

University of Zululand, (2010), Self-Evaluation Portfolio for the Institutional Audit.

University of Zululand, (ND), 1960-2005: 45 Years of Excellence, KwaDlangezwa.

Vandegrift, D., Lockshiss, A. and Larh, M. (2012), "The town versus gown: the effects of a college on housing prices and the tax base", Growth and change, vol. 43, no. 2, p. 304-334.

Woods, M. (2012), "New directions in rural studies?", Journal of Rural Studies, vol. 28, p. 1-4. 